\title{
Penetapan Parameter Standar Simplisia dan Ekstrak Etanol Daun Ganitri (Elaeocarpus serratus L.)
}

\section{Establishment of Standard Parameters of Crude Drugs and Ethanolic Extract of Ceylon Olive (Elaeocarpus serratus L.) Leaves}

\author{
Naelaz Zukhruf Wakhidatul Kiromah*, Sinta Wahyu Septiani, Wahyu Rahmatulloh, \\ Ari Purnomo Aji \\ Program Studi Farmasi Program Sarjana, \\ Sekolah Tinggi Ilmu Kesehatan Muhammadiyah Gombong \\ Jl. Yos Sudarso No.461, Gombong, Kebumen 54412, Indonesia \\ *Corresponding author email: naela.zukhruf18@stimugo.co.id
}

Received 07-01-2020 Accepted 18-05-2020 Available online 01-07-2020

\begin{abstract}
Ceylon olive (Elaeocarpus serratus L.) leaves have shown many pharmacological effects. Standardization of crude drug and extract needs to be conducted to assure the quality of the said material and further to support the pharmacological, pharmacokinetics, and toxicity effects. Standardization of Ceylon olive leaf extract is carried out to determine the standard parameters of crude drug and ethanolic extract of Ceylon olive leaves. Determination of the quality standard of crude drug and extract includes specific and non-specific parameters. The extract was obtained from a $70 \%$ ethanol maceration method with a yield of $16.02 \%$. Macroscopic observations showed crude drugs of Ceylon olive leaves occurred as green in color, lanceolate leaves, 2-12 $\mathrm{mm}$ stems, and jagged leaves not deep, black spots, 10-15 side leaf bones, 6-18 cm long and 2-6 cm wide. Organoleptic of ethanolic extract of Ceylon olive showed thick consistency, blackish-brown colored, with a distinctive odor and a bitter taste. The water-soluble extractive value in crude drugs and extract was 16.48 and $51.54 \%$, while the ethanolsoluble extractive value was 23.17 and $53.67 \%$, respectively. The extract contained tannins, flavonoids, terpenoids, and saponins. Moisture content in the crude drugs and extracts was 22.09 and $25.53 \%$. Total ash content in crude drugs and extracts was 33.53 and $30.62 \%$, while their acid-insoluble ash content was 15.94 and $10.06 \%$, respectively. Loss on drying of the crude drugs and extracts was 20.52 and $23.84 \%$ respectively. As the standard parameters of crude drugs and ethanolic extract of Ceylon olive leaves are not yet included in any formal monograph in Indonesia, the values of parameters reported in this study should be used as the reference of the standard quality parameter for those materials.
\end{abstract}

Key words: ceylon olive leaves, crude drug, extract, standardization. 


\section{Introduction}

Indonesia is one of the countries that have a large number of plants, where 30,000 species are high-level plants and which have been botany identified about 1000 types of plants (Saifudin et al., 2011). The development and use of medicinal plants in Indonesia have been directed to improve health, prevent disease, restore health, and cure disease. However, in the field of services, traditional medicine cannot be used like modern medicine because it must be tested in the field of efficacy and safety of herbal medicines (Hariyati, 2005). Standardization of extracts or quality tests needs to be done to support the pharmacological, pharmacokinetic and toxicity effects.

One of the plants that have the potential to be developed as an alternative treatment is ceylon olive. The ceylon olive plant (Elaeocarpus ganitrus Roxb) is a plant known as a sacred and revered tree in India, known as Rudraksha. The ceylon olive plant (Elaocarpus ganitrus Roxb) has been used as traditional Hindu medicine (ayuverdi). Several studies state that ceylon olive plants both seeds and leaves have pharmacological activities, namely anti-inflammatory and analgesic, CNS, sedative, hypnotic, antidepressant, antiasthma, antidiabetic, antibacterial, antifungal, and anticonvulsant (Swati et al., 2008). Chemical content of ceylon olive plants that can provide pharmacological effects, namely alkaloids, phenolics, tannins, flavonoids and fatty acids (Kumar et al., 2014).
Research and development of ceylon olive plants into traditional medicines, standardized herbal medicines, or phytopharmaca will always be carried out (Lestari et al., 2018). Based on the great potential of ceylon olive leaves, it is necessary to standardize raw materials for crude drug and extracts. The aim of standardization is to maintain stability and safety and to maintain consistency in the content of active compounds in crude drug and extracts (Utami et al., 2017).

The process of standardization of ceylon olive leaves requires the raw material requirements of crude drug and extracts listed in the general monograph, namely medicinal material, and Indonesian herbal pharmacopoeia. However, special raw materials of crude drug and ceylon olive leaf extracts are not yet listed in general monographs. This standardization research of crude drug and ceylon olive leaf extract is expected to be a reference as a parameter of the quality standard of crude drug and ceylon olive leaf extract.

\section{Method}

Research Instrument

The ingredients used are ceylon olive leaves, $70 \%$ ethanol, distilled water, chloroform, $\mathrm{HCl}$, Dragendroff reagent, Mayer reagent, $\mathrm{FeCl}_{3}$, anhydrous acetic acid, $\mathrm{H}_{2} \mathrm{SO}_{4}$.

\section{Research Courses}

1. Crude drug preparation ceylon olive plants were obtained from Pagebangan Village, Karangagayam District, Kebumen 
Regency. Ceylon olive was determined at the General Soedirman University's Plant Taxonomy Laboratory. Plant parts used are leaves. The leaves of ceylon olive 1000 grams of fresh are cleaned and washed using flowing water followed by aquadest to remove foreign particles. Ceylon olive leaves are then dried by indirectly drying in the sun or using an oven at 25 으. Dried ceylon olive leaves are blended to form a fine powder.

2. Extraction

Ceylon olive leaf extraction was carried out using maceration method. Ceylon olive leaf fine powder was immersed in aquadest solvent, 70\% ethanol solvent, and $70 \%$ methanol each with a ratio of $1: 10$. Immersion carried out for 72 hours with occasional stirring. The maceration results are filtered using filter paper and evaporated using a rotary evaporator at $40{ }^{\circ} \mathrm{C}$ until an extract is formed. Before the ceylon olive leaf extract is used, the extract can be stored in a refrigerator at $4{ }^{\circ} \mathrm{C}$.

3. Standardization of specific parameters a. Identity

Descriptions of nomenclature are the names of crude drug and extracts, latin names of plants, parts of plants used, and names of Indonesian plants (Depkes RI, 2000).

b. Organoleptic examination

Organoleptic crude drug and extract examination include shape, odour, taste, and colour. The statements "odourless", "practically odourless", "characteristic odour is weak" or otherwise are determined by observation after the material has been exposed to air for 15 minutes. 15 minutes is calculated after the container containing no more than $25 \mathrm{~g}$ of material is opened. For containers containing more than $25 \mathrm{~g}$ of the fixing material, it is carried out after approximately $25 \mathrm{~g}$ of the material is transferred into a $100 \mathrm{~mL}$ vaporizer cup (Depkes RI, 2000).

c. Macroscopic test

Macroscopic tests are performed using a magnifying glass or without tools. This method is carried out to look for the morphological specificity and colour crude drug of ceylon olive leaves (Eliyanoor, 2012).

d. Chemical content test

Alkaloid test

The extract was mixed with $5 \mathrm{~mL}$ of chloroform and $5 \mathrm{~mL}$ of ammonia then heated, shaken, and filtered. 5 drops of $2 \mathrm{~N}$ sulfuric acid were added to each filtrate, then shake and settle. The top of each filtrate was taken and tested with Mayer, Wager, and Dragendorf reagents. The formation of white, brown, and orange deposits indicates the presence of alkaloids (Harborne, 1987; Utami et al., 2017). 


\section{Flavonoid test}

The extract was mixed with $3 \mathrm{~mL}$ of $70 \%$ ethanol then shaken, heated and shaken again, then filtered. The filtrate obtained was added to $0.1 \mathrm{~g}$ of $\mathrm{Mg}$ powder and 2 drops of concentrated $\mathrm{HCl}$. The formation of red colour in the ethanol layer that shows the presence of flavonoids (Harborne, 1987).

\section{Tannin test}

The extract was extracted with $10 \mathrm{~mL}$ of air then filtered. The filtrate was diluted with water until it was colourless. The solution was taken as much as $2 \mathrm{~mL}$ and added 2 drops of $\mathrm{FeCl} 1 \%$. The formation of a greenish-brown or blackish blue colour indicates the presence of tannins (Harborne, 1987).

\section{Terpenoid and steroid test}

The extract was added with $3 \mathrm{~mL}$ chloroform or $3 \mathrm{~mL} 70 \%$ ethanol and added $2 \mathrm{~mL}$ concentrated sulfuric acid and $2 \mathrm{~mL}$ anhydrous acetic acid. Discolouration from purple to blue or green indicates the presence of steroid compounds and the formation of a brownish colour between surfaces indicates the presence of terpenoid compounds (Harborne, 1987).

\section{Saponin test}

The extract was put into a test tube, $10 \mathrm{~mL}$ of hot air was added, cooled and then shaken vigorously for 10 seconds. Positively contains saponin if the foam is formed as high as 1-10 cm for not less than 10 minutes and when receiving 1 drop of $\mathrm{HCl} 2 \mathrm{~N}$, the foam does not disappear (Depkes RI, 1995).

e. Water-soluble extractive value

Crude drug and extract as much as $5 \mathrm{~g}$ each were weighed, put into a clogged pumpkin, add $100 \mathrm{~mL}$ of saturated chloroform water. Shake it repeatedly for the first 6 hours, leave it for 18 hours. The filtrate is filtered and evaporated to dryness in a shallow flat-bottomed cup that has been tamed. The residue is heated at $105{ }^{\circ} \mathrm{C}$ to a fixed weight, calculate the level in\% airsoluble extract (Depkes RI, 2008).

d. Ethanol-soluble extractive value Simplisia and extract as much as $5 \mathrm{~g}$ each, put into a clogged pumpkin, add $100 \mathrm{~mL}$ of ethanol $\mathrm{P}$. Shake it repeatedly for the first 6 hours, leave for 18 hours. The filtrate is filtered and evaporated to dryness in a shallow flatbottomed cup that has been tamed. The residue is heated at $105{ }^{\circ} \mathrm{C}$ to a fixed weight, calculate the level in\% ethanol-soluble extract (Depkes RI, 2008).

4. Standardization of non-specific parameters

a. Determination of total ash content Crude drugs and extracts of $2 \mathrm{~g}$ each were weighed and put into a cylindrical silicate crucible which was incanded and tamed, incandescent slowly until the temperature caused the organic 
compounds and their derivatives to be degraded and evaporated until the only mineral and inorganic elements remained at a temperature of $600 \pm 25{ }^{\circ} \mathrm{C}$, cool and weigh. Total ash content is calculated against the weight of the test material, expressed in \% w/w (Depkes RI, 2008).

b. Determination of acid-insoluble ash content

Ash obtained at the determination of total ash content was boiled with $25 \mathrm{~mL}$ dilute hydrochloric acid LP for 5 minutes. Parts that are not soluble in acid are collected, filtered through ashfree filter paper, ash content which is insoluble in acid is calculated against the weight of the test material, expressed in \% w/w (Depkes RI, 2008).

c. Determination of water content

Weighed the number of crude drugs in a cup that had been put in jail. Dried at $105^{\circ} \mathrm{C}$ for 5 hours and weighed (Depkes RI, 2000).

d. Determination of drying losses

Simplisia and extracts of $2 \mathrm{~g}$ each were put into a crushed porcelain crucible which had been previously heated at $105{ }^{\circ} \mathrm{C}$ for 30 minutes and was put in the tara. Crush is put into the oven in the open crucible, dry at $105{ }^{\circ} \mathrm{C}$ until the weight remains, cool in the excitator. Replication is done three times then the percentage is calculated (Depkes RI, 2000).

\section{Results and Discussion}

Ceylon olive leaf has potential as an anti-inflammatory, antioxidant, antimicrobial, and antidiabetic drug (Kumar et al., 2014). The purpose of standardization is to guarantee the quality and safety standards of medicinal plant extracts. Determination of quality standards carried out includes specific and non-specific parameters. Determination of this standardization value needs a reference to indicate that the crude drug and extract meet the specified requirements. The official standardization guidelines for ceylon olive leaves have not been listed in the Ministry of Health publications or other sources, so as a reference this research is to use general requirements. The sample used in this study was crude drug and ethanol extract of ceylon olive leaves. The extract was obtained from the extraction using maceration method for $3 \times 24$ hours. The thick extract was obtained as much as 80.078 grams with a yield of $16.02 \%$. Crude extracts and extracts were then standardized.

The crude drug and extract identity parameters are intended to provide the identity of the objective name specifically (Depkes RI, 2000). Table 1 shows the results of the examination of the identity of the crude drug and the extract.

Macroscopic testing aims to find the specificity of the morphological shape and colour Crude drug of Ceylon olive leaves (Eliyanoor, 2012). The results of the macroscopic examination showed simplicity green ceylon olive 
leaves, lanceolate leaves, 2-12 $\mathrm{mm}$ stems, the base of the strands turned gradually into stems, jagged leaves were not deep, jagged, black spots, 10-15 side leaf bones, 6-18 cm long, and 2-6 cm wide.

The organoleptic examination involves describing the shape, colour, smell, and taste. Simplisia has a strong characteristic odour, bitter taste, and brownish-green colour. While the extract is in the form of a thick extract, with a strong odour, bitter taste and black colour. The organoleptic parameters of the extract aim to provide an initial introduction to crude drug and extract using the five senses (Depkes RI, 2000).

The chemical content test aims to provide an initial overview of the chemical composition (Depkes RI, 2000). The chemical content test was carried out on the ethanol extract of ceylon olive leaves, the results obtained showed that the ethanol extract of ceylon olive leaves contained terpenoids, flavonoids, saponins, and tannins (Table 2).

Table 1. The results of the examination of the identity of crude drugs and ethanolic extract of ceylon olive leaves

\begin{tabular}{ll}
\hline \multicolumn{1}{c}{ Description } & \multicolumn{1}{c}{ Results } \\
\hline Name of crude drug & Elaeocarpus crude drug \\
Name of thick extract & Elaeocarpus extractum spissum \\
Latin names of plant & Elaeocarpus serratus L. \\
The part of plant & Elaeocarpus folium \\
Indonesian name of plant & Ganitri \\
\hline
\end{tabular}

Table 2. The chemical content of ethanolic extract of ceylon olive leaves

\begin{tabular}{|c|c|c|c|}
\hline \multicolumn{2}{|c|}{ Compound group } & Result & Information \\
\hline \multirow[t]{3}{*}{ Alkaloids } & - Mayer & Greenish brown & - \\
\hline & - Wagner & Greenish brown & - \\
\hline & - Dragendorf & Yellowish - brown & - \\
\hline Steroids & & Yellow & - \\
\hline Terpenoid & & Brownish on the surface & + \\
\hline Flavonoids & & The red color in the ethanol layer & + \\
\hline Saponin & & Shaped foam & + \\
\hline Tanin & & Greenish brown & + \\
\hline
\end{tabular}

Determination of the levels of water-soluble and ethanol-soluble extracts aims to estimate the levels of active compounds based on polarity properties. Determination of levels of water-soluble and ethanol compounds is not related to pharmacological effects but is an estimate of compounds that are polar (water-soluble) and active compounds semipolar-nonpolar (soluble ethanol). The results of the level of water-soluble compounds obtained from 
genitri leaf crude drug (Table 3 ) is $16.48 \%$ and the concentration of soluble ethanol compounds is $23.17 \%$. Testing the levels of water-soluble and ethanolsoluble compounds in the ceylon olive leaf extract each resulted in $51.54 \%$ and $53.67 \%$. The results obtained either crude drug or extract showed ceylon olive leaf compounds more watersoluble than ethanol. This proves that the polar compounds contained in ceylon olive leaves more than nonpolar compounds.

Determination of nonspecific crude drug parameters includes water content, drying losses, ash content, and acid insoluble ash content (Table 3-4).
The results of the determination of the nonspecific parameters crude drug and extract can be seen in Table 4. The loss on drying test shows the amount of compound contained in the extract and is lost or volatile in the drying process. The weight of shrinkage or shrinkage of drying becomes the parameters of an extract to maintain quality in order to avoid mould growth (Safitri, 2008). The result of crude drug shrinkage testing was $20.52 \%$. Whereas in the extract, the results of the drying shrinkage test were 23.84\%. Masses that can be lost by heating include water molecules, essential oils and ethanol solvents.

Table 3. Determination of levels of water and ethanol-soluble extractive value

\begin{tabular}{lcc}
\hline \multicolumn{1}{c}{ Type of solvent-soluble test } & \multicolumn{2}{c}{ Result (\%) } \\
\cline { 2 - 3 } & Crude drug & Extract \\
\hline Water-soluble extraxtive value & 16.48 & 51.54 \\
Ethanol-soluble extraxtive value & 23.17 & 53.67 \\
\hline
\end{tabular}

Table 4. Non-specific parameters for standardization of crude drug and extract of Ceylon olive leaves

\begin{tabular}{lcc}
\hline \multirow{2}{*}{ Non-specific parameters } & \multicolumn{2}{c}{ Result (\%) } \\
\cline { 2 - 3 } & Crude drug & Extract \\
\hline Total ash content & 33.53 & 30.62 \\
Acid-insoluble ash content & 15.94 & 10.06 \\
Water content & 22.09 & 25.53 \\
Loss on drying & 20.52 & 23.84 \\
\hline
\end{tabular}

Moisture content is a parameter for determining residual water after the drying process. The crude drug test content of water content obtained was $22.09 \%$ and the test results obtained $25.53 \%$ of extract water content. The water content was obtained at the crude drug and extract respectively according to the quality requirements of $\leq 10 \%$. The thick extract has a moisture content between 5-30\% (Voigt, 1994). Determination of water content is also related to the purity of the extract. Water content that is too high (>10\%) causes microbial growth which will reduce the stability of the extract (Saifudin et al., 2011). 
Ash content measurement is intended to determine the amount of inorganic material or minerals left after the greying process. At this stage, the crude drug and extract are heated at 600 ${ }^{\circ} \mathrm{C}$ until the organic compound evaporates until only the mineral (inorganic) elements remain. The results of the crude drug ash content were $33.53 \%$ and the extract was $30.62 \%$. High ash content shows high internal mineral content in ceylon olive leaves. The higher the ash content obtained, the mineral content in the material is also higher.

Acid insoluble ash levels indicate the presence of acid-insoluble minerals or metals in a product (Depkes RI, 2000). Acid insoluble ash content in crude drug was $15.94 \%$ and in extracts, it was $10.06 \%$. High levels of acid-insoluble ash reflect the presence of silicate content derived from soil or sand, soil and silver metal elements, lead and mercury (Guntarti et al., 2015).

\section{Conclusion}

Standardization of crude drug and ceylon olive leaf extract was obtained that the ceylon olive leaf extract had a thick consistency, brownish-black, distinctive smell and bitter taste. The level of water-soluble compound crude drug is $16.48 \%$ and the concentration of soluble ethanol compound is $23.17 \%$ while the watersoluble compound in the extract is $51.54 \%$ and the level of ethanol-soluble compound is $53.67 \%$. Ceylon olive leaf extract contains tannins, saponins, terpenoids and flavonoids. Nonspecific parameters, water content acquisition in crude drug and extracts $>10 \%$ each. Drying losses were obtained at $20.52 \%$ simplisa and $30.62 \%$ extracts. The result of the total ash content in crude drug was $33.53 \%$ and in extract $30.62 \%$. The acid insoluble ash content was 15.94\% crude drug and $10.06 \%$ extract.

\section{Reference}

Depkes RI. 2008. Farmakope Herbal Indonesia. Jakarta: Departemen Kesehatan Republik Indonesia.

Depkes RI. 1995. Farmakope Indonesia. Edisi IV. Jakarta: Direktorat Jendral Pengawasan Obat dan Makanan.

Depkes RI. 2000. Parameter Standar Umum Ekstrak Tumbuhan Obat. $1^{\text {st }} \quad$ Ed. Jakarta: Dirjen Pengawasan Obat dan Makanan.

Eliyanoor, B. 2012. Penuntun Praktikum Farmakognosi II. Jakarta: EGC.

Guntarti, A., Sholehah, K., Fistianingrum, W. 2015. Penentuan parameter non spesifik ekstrak etanol kulit buah manggis (Garcinia mangostana) pada variasi asal daerah. Farmasains, 2(5):202207.

Harborne, J. 1987. Metode Fitokimia, Penuntun Cara Modern Menganalisa Tumbuhan. Bandung: ITB.

Hariyati, S. 2005. Standardisasi ekstrak, tumbuhan obat indonesia, salah satu tahapan penting dalam pengembangan obat asli 
Indonesia. Info POM, 6(4):1-5.

Kumar, G., Karthik, L. and Bhaskara Rao, B. 2014. A review on medicinal properties of Elaeocarpus ganitrus Roxb. ex G. Don. (Elaeocarpaceae). Research Journal of Pharmacy and Technology, 7(10):1184-1186.

Lestari, R.F., Suhaimi, Wildaniah, W. 2018. Penetapan parameter standar simplisia dan ekstrak etanol daun kratom (Mitragyna speciosa Korth) yang tumbuh di Kabupaten Kapuas Hulu dan Kabupaten Melawi. Jurnal Insan Farmasi Indonesia, 1(1):72-84.

Safitri, R. 2008. Penetapan beberapa parameter spesifik dan nonspesifik ekstrak etanol daun alpokat (Persea americana Mill.). Skripsi. Departemen Farmasi, FMIPA, Universitas Indonesia.

Saifudin, A., Rahayu, V., Teruna, H.Y. 2011. Standarisasi Bahan Obat Alam. Edisi Pertama. Yogyakarta: Graha IImu.

Utami, Y.P., Umar, A.H., Syahruni, R., Kadullah, I. 2017. Standardisasi simplisia dan ekstrak etanol daun leilem (Clerodendrum minahassae Teisjm. \& Binn.). Journal of Pharmaceutical and Medicinal Sciences, 2(1):32-39.

Voigt, R. 1994. Buku Pelajaran Teknologi Farmasi. Yogyakarta: Gadjah Mada University Press. 